\title{
AN EXPERIMENTAL STUDY ON THE USE OF POLYPROPYLENE WASTE IN BITUMINOUS MIX
}

\author{
H. S. Otuoze ${ }^{1, *}$ and A. A. Shuaibu ${ }^{2}$ \\ 1,2, DePartment of Civil EngineERING, Ahmadu Bello University, Zaria, Kaduna STATE, NiGERIA

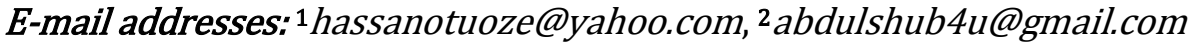

\begin{abstract}
The work focuses on assessing the Marshall properties of High Density Polypropylene (HDPP) waste and its potentiality to mitigate pavement failures due to environmental and traffic loading. Based on design, 4.5, 5.0, 5.5, 6.0 and 6.5\% bitumen contents were arbitrarily selected to prepare one hundred and five (105) Marshall specimens having respectively 0, 0.5, 1.0, 1.5, 2.0, 2.5 and 3.0\% HDPP waste in Polymer Modified (PM) asphalt concrete. The specimens were tested for stability, flow, compacted density of the mix (CDM) and void analysis. Optimum parameter for Marshall properties obtained are $27.68 \mathrm{kN}, 2.54 \mathrm{~mm}, 2.45 \mathrm{~g} / \mathrm{cm}^{3}, 3.39 \%, 16.2 \%$ and $74.10 \%$ respectively for stability, flow, CDM, VIM, VMA and VFB. The results revealed enhanced engineering properties of $2 \%$ HDPP at an optimal bitumen content of 5.5\% and could satisfy strength and durability requirements of heavy traffic situation.
\end{abstract}

Keywords: High Density Polypropylene, Bitumen, Asphalt, Strength

NOTATIONS:

HDPE: High Density Polyethylene

LDPE: Low Density Polyethylene
VIM: Void in Mix

VFB: void Filled with Bitumen

VMA: Void in Mineral Aggregate
CDM: Compacted Density of Mix

EAL: Equivalent Axle Load

PM: Polymer Modified

\section{INTRODUCTION}

Transportation in all history has remained the cornerstone of civilization and an index of economic growth and development of every nation [1]. Highway transport mode in Nigeria, like many developing countries, accounts for $95 \%$ of all transport movements and this is not without the inevitable consequences of pavement failures induced by material properties, excessive traffic loading and environmental factors [2 4].

Though, long term cost puts rigid pavement at comparative cost advantage, flexible pavement still remains the choice of low income countries because of its lower initial cost of construction. Although, about N1.4 trillion had been appropriated for investment in the road sector infrastructures between 1999 and 2012 by Nigerian federal government [1], distresses like ravelling, cracking, rutting, creep, corrugation, stripping and pot-holing are some of the major service problems of the roads leading to high rates of accident [5].

Pavement is the structural materials laid down on an area intended to sustain vehicular or foot traffic, such as a road or walkway and its structure normally consists of a few layered materials arranged from the topmost (surfacing) in the order of strength to ensure adequate stability under traffic loads [6]. A number of factors such as poor materials selection and quality, design and construction lapses, climatic factors; maintenance negligence and excessive traffic loading are responsible for pavement failures [7]; [5]. Increasing vehicular traffic volume on roads as the main source of connectivity and inefficient stake of government on public transport has increased the economic malady and lack of return on investment as pavements fail to reach the design life [8]. Also, constant overload beyond $80 \mathrm{kN}$ (Nigerian legal axle limit) by trucks has made design projection life meaningless [9]. In view of that, efforts to strengthen and increase pavement life have become enormous challenge to government, road agencies and researchers.

It is important to use mixes flexible enough at low service temperature to reduce excessive failures like pavement cracking and to be stiff enough at high service temperature to prevent creep, rutting which are time and temperature dependent [10]. Pavement distresses and poor performance of bituminous mixtures under increased traffic volume and heavy axle loading have led to increased development and usage of bitumen modifier 
[11] and fibre reinforcement [12] for bituminous mixtures.

A number of polymers and fibre materials such as thermoplastics - ethylene vinyl acetate (EVA), low density polyethylene (LDPE), high density polyethylene (HDPE) and ethylene-propylene-diene (EPDM) have been used in asphalt mix. Elastomers like styrenebutadiene-styrene (SBS), styrene-butadiene random copolymers (SBR) and styrene-isoprene-styrene (SIS) and poly-butadiene-base materials have also been used[11]. Others are asbestos, glass, carbon and cellulose fibres which also impact on the desired properties of pavement and suffice to mitigate the distresses. The materials have been used either as bitumen modifier called wet process [13]; [14]. or fibre reinforcement called dry process [15]. The ultimate goal of introducing the materials into asphalt mix is to increase the service life of the pavement by preventing creep and fatigue failures and reflective cracks.

Approximately 30,000,000 tons of HDPP was consumed worldwide in 2001 and the products generate monumental waste disposal and environmental problems after their use [16].In Nigeria, polypropylene production has been largely dependent on the two local petrochemical industries in Eleme and Warri with production capacities of 90,000 and 35, 0000tons per annum respectively [43]. Polypropylene (PP) is known to have good heat and chemical resistance; resistance to deformation at elevated temperatures, high stiffness, surface hardness and toughness at normal temperature [17].The differences between HDPP and LDPP are the densities and crystalline or amorphous structure depending on the desired phase. The focus of this research is to evaluate the potentials of HDPP waste which is more abundant and readily available than LDPP to mitigate pavement distresses. The research is aimed at assessing the possibility of using HDPP waste to improve engineering properties of asphalt concrete.

\section{LITERATURE REVIEW}

\subsection{Bitumen}

[18] depicted bitumen as having "colloidal system, with asphaltenes forming the centres of micelle and having a more pronounced aromatic nature. The asphaltenes are assumed to be surrounded by lighter constituents of less aromatic nature, and there were no distinct interphases between micelles and the medium surrounding it". Micelles may be visualized in terms of surfactants or compounds that lower surface or interfacial tension and an aggregation of colloids or surfactant molecules coming together from association of several unit cells [19].

Basically, three constituent mixtures are largely identified in bitumen - asphaltenes, asphaltic resins and oily constituents (aromatics and saturates).The acronym (SARA's) was conveniently used by [20]; [21] to depict the presence of saturates (S), aromatics (A), resins (R), and asphaltenes (As) in bitumen.

\subsection{Characterisation of Polypropylene Material}

Polypropylene is one of the most widely used polymers in the world because of the widespread availability and low manufacturing cost. The reactivity of propylene is a result of the olefinic double bond in methyl-ethylene $\left(\mathrm{H}_{2} \mathrm{C}=\mathrm{CHCH}_{2}\right)$, which gives rise to addition reactions. With respect to the regularity of the methyl group placement relative to the other methyl groups along the chain backbone otherwise called the stereospecificity of the polymerization, [22] provided the models of three limiting classifications of stereospecificity in PP isotactic polypropylene (iPP), syndiotactic polypropylene (sPP) and atactic polypropylene (aPP).

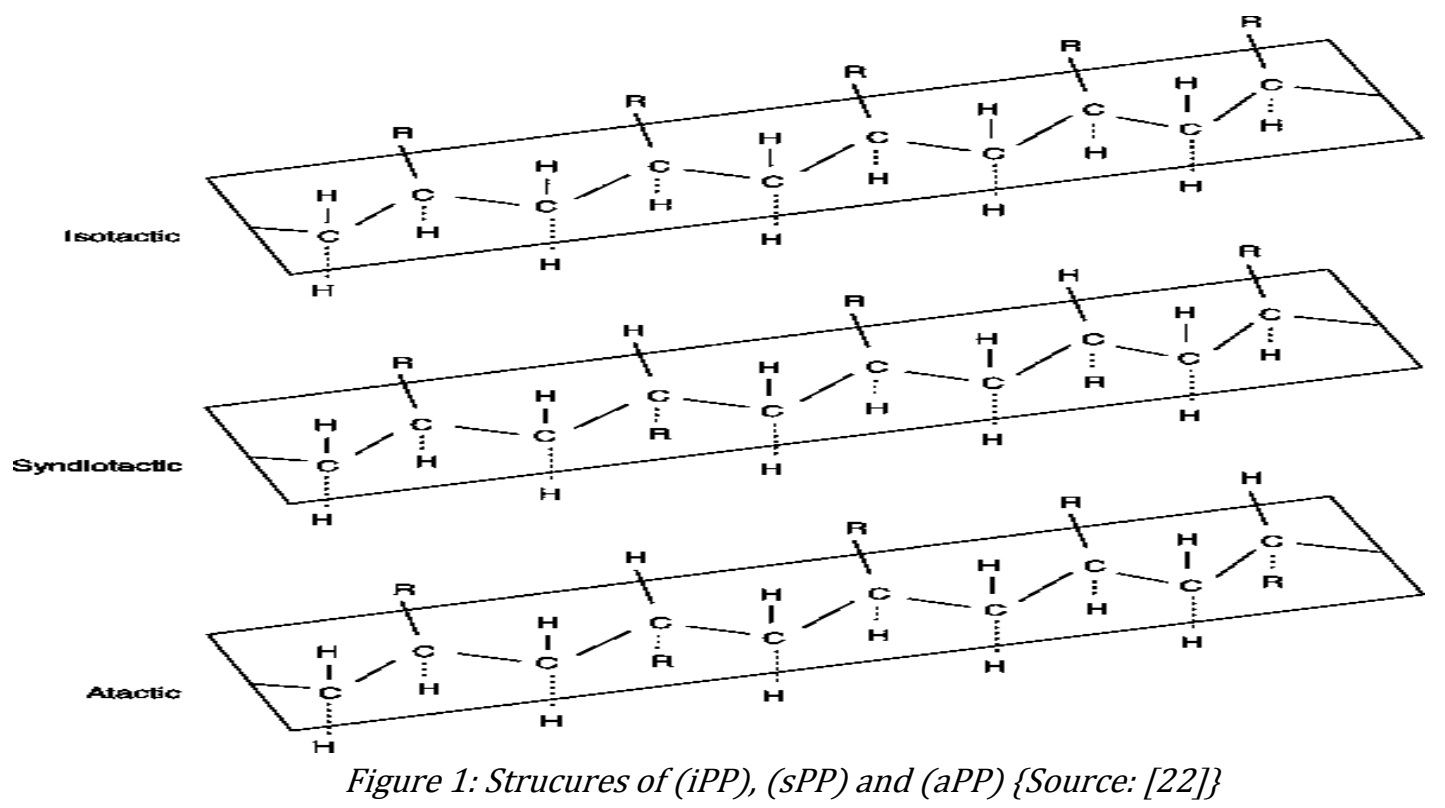




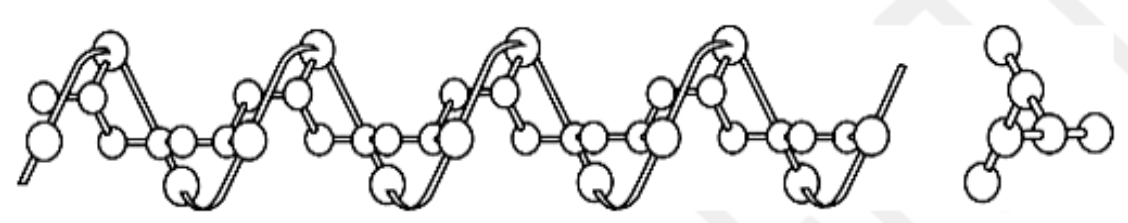

Figure 2: Conformation chain of (iPP) - \{Source: [23]\}

The isotactic polypropylene (iPP) has all of the methyl groups having the same configuration with respect to the polymer backbone while syndiotactic polypropylene (sPP) has the methyl groups have alternating configurations. The atactic polypropylene (aPP) has a random configuration. iPP is overwhelmingly the most commercially significant form of PP for most products [23] and[24]Figure 1 shows the Strucures of (iPP), (sPP) and (aPP) isomers [22]. Figure 2 is the depiction of chain conformation of isotactic polypropylene (iPP). The density ( $\rho$ ) of iPP in the $\alpha$-form shows variation between the limit of $100 \%$ amorphous ( $\rho \mathrm{a}=0.850$ to $0.855 \mathrm{~g} / \mathrm{cm}^{3}$ ) and $100 \%$ crystalline ( $\rho c=0.936$ to $0.946 \mathrm{~g} / \mathrm{cm}^{3}$ ) [25].In this way, the measured mass density $\rho$ gives a measure of the crystallinity. Density gradient techniqueis mostly used to measure $\rho$-values [26].

\section{METHODOLOGY}

Preliminary tests were conducted on bitumen coarse and fine aggregates and filler in Department of Civil Engineering Ahmadu Bello University, Zaria. to ascertain whether they meet the qualities viable for use as satisfying the various code standards requirements.

\subsection{Preliminary Test on HDPP Modified Bitumen}

Tests were conducted to determine the consistency, purity and safety of unmodified and HDPP polymer modified bitumen $(0-3 \%)$. The tests conducted were according to the recommendations of the American Society for Material Testing (ASTM) relevant code standards for the $60 / 70$ penetration bitumen used. As shown in Table 1, the tests conducted are ductility, penetration, softening point, specific gravity, solubility and flash and fire point tests. Also, thin film oven test (TFOT) was included in the characterization of HDPP bitumen to evaluate the short term ageing which affects the durability of the mix.

\subsection{Preliminary Tests on Mineral Aggregates}

Strength characterization, shape, moisture absorption and gravity tests were conducted on aggregates to assess their quality. Table 2 shows the results of the tests with their respective code recommendations.

Table 1: Results of Consistency, Purity and Safety Tests of Bitumen

\begin{tabular}{|c|c|c|c|c|c|c|c|c|c|}
\hline \multirow{2}{*}{ Test Conducted } & \multirow{2}{*}{$\begin{array}{l}\text { ASTM } \\
\text { Code }\end{array}$} & \multirow{2}{*}{$\begin{array}{l}\text { Code } \\
\text { Used }\end{array}$} & \multicolumn{7}{|c|}{ Test Result for \% HDPP } \\
\hline & & & 0 & 0.5 & 1.0 & 1.5 & 2.0 & 2.5 & 3.0 \\
\hline $\begin{array}{c}\text { Penetration at } 25^{\circ} \mathrm{C}, \\
0.1 \mathrm{~mm}\end{array}$ & $\begin{array}{l}\text { ASTM D5- } \\
\quad 97\end{array}$ & $60-70$ & 67.7 & 62.9 & 53.8 & 45.2 & 38.5 & 30.9 & 22.5 \\
\hline Penetration Index (PI) & 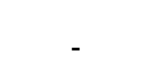 & $\begin{array}{l}-2 \text { to } \\
+2\end{array}$ & -0.338 & +0.239 & +0.222 & 0.526 & +1.516 & +1.881 & 2.146 \\
\hline Softening point $\left({ }^{\circ} \mathrm{C}\right)$ & $\begin{array}{l}\text { ASTM } \\
\text { D36-95 }\end{array}$ & $46-56$ & 50.5 & 53.6 & 55.3 & 58.7 & 66.0 & 71.3 & 77.8 \\
\hline $\begin{array}{c}\text { Flash point (Cleveland } \\
\text { open cup), }{ }^{\circ} \mathrm{C}\end{array}$ & $\begin{array}{l}\text { ASTM } \\
\text { D92-02 }\end{array}$ & $\begin{array}{l}\text { Min. } \\
232\end{array}$ & 295.2 & 311.4 & 317.0 & 322.6 & 330.9 & 335.6 & 342.5 \\
\hline $\begin{array}{c}\text { Fire point Cleveland } \\
\text { cup), }{ }^{\circ} \mathrm{C}\end{array}$ & $\begin{array}{l}\text { ASTM } \\
\text { D92-02 }\end{array}$ & $\begin{array}{l}\text { Min. } \\
232\end{array}$ & 306.5 & 317.2 & 326.8 & 334.7 & 341.5 & 349.6 & 358.4 \\
\hline Ductility at $25^{\circ} \mathrm{C}, \mathrm{cm}$ & $\begin{array}{l}\text { ASTM } \\
\text { D113 }\end{array}$ & Min. 50 & 122.4 & 107.2 & 88.6 & 72.4 & 54.3 & 42.8 & 22.6 \\
\hline $\begin{array}{l}\text { Specific gravity at } 25^{\circ} \mathrm{C} \\
\text { (g/cc) }\end{array}$ & $\begin{array}{l}\text { ASTM } \\
\text { D70 }\end{array}$ & $\begin{array}{c}0.97- \\
1.02\end{array}$ & 1.022 & 1.015 & 1.011 & 1.008 & 1.005 & 1.003 & 1.001 \\
\hline $\begin{array}{c}\text { Solubility in } \\
\text { trichloroethylene, } \%\end{array}$ & $\begin{array}{l}\text { ASTM } \\
\text { D2042 }\end{array}$ & Min. 99 & 99.02 & - & - & - & - & - & - \\
\hline \multicolumn{10}{|c|}{ Properties of residue Thin Film Oven Test (TFOT) - $\left\{\right.$ Heating for 5hrs at $\left.163^{\circ} \mathrm{C}\right\}$} \\
\hline Ductility at $25^{\circ} \mathrm{C}, \mathrm{cm}$ & $\begin{array}{l}\text { ASTM } \\
\text { D113 }\end{array}$ & Min. 50 & 59.2 & 56.4 & 54.0 & 52.5 & 50.5 & 48.7 & 46.5 \\
\hline $\begin{array}{l}\text { Retained penetration } \\
\text { ( } \% \text { of original) }\end{array}$ & ASTM D5 & Min. 54 & 78.3 & 72.6 & 65.9 & 59.4 & 56.0 & 50.2 & 44.8 \\
\hline $\begin{array}{c}\text { Loss on heating ( } \% \text { by } \\
\text { mass) }\end{array}$ & $\begin{array}{l}\text { ASTM D6- } \\
95\end{array}$ & $\begin{array}{c}\text { Max. } \\
0.5\end{array}$ & 0.23 & 0.25 & 0.38 & 0.41 & 0.42 & 0.46 & 0.59 \\
\hline
\end{tabular}




\subsection{Consistency Tests on Cement Filler}

Tests conducted on cement filler include specific gravity, setting time and soundness and Table 3 shows the results.

\subsection{Aggregate Material Sampling, Grading, Proportioning and Blending \\ 3.4.1 Aggregate Sampling and Determination of Particle Size Distribution (PSD)}

Aggregate materials were sampled according to the recommendation of BS [27] and particle size distribution was conducted according to [28].The result of PSD for Coarse and fine aggregates and cement filler are shown in Tables 4.

\subsection{Design Bitumen Content}

The method of [29]was used to estimate expected Design Bitumen Content (DBC) given by:

$$
D B C=0.035 a+0.04 b+K c+F
$$

Since a is the \% of mineral aggregate retained on the $2.36 \mathrm{~mm}$ sieve $=55.5 \%, \mathrm{~b}$ is the $\%$ of aggregate passing $2.36 \mathrm{~mm}$ sieve and retained on $0.075 \mathrm{~mm}$ sieve $=38 \%$, c is the $=\%$ of mineral aggregate passing the $0.075 \mathrm{~mm}$ sieve $=6.5 \%, \mathrm{~K}$ is the 0.18 for $6-10 \%$ passing the $0.075 \mathrm{~mm}$ sieve $=0.18$ and $\mathrm{F}$ is the $0-2 \%$ for absorption of bitumen $=0.7$

Therefore,

$$
\begin{gathered}
D B C=0.035(55.5)+0.04(38)+0.18(6.5)+0.7=1 \\
=5.332=5.5 \%(\text { appr })
\end{gathered}
$$

The recommendation of [29] requires two other points at $0.5 \%$ above and below the optimum DBC which serves as the optimum. Thus, the ranges of bitumen content to be adopted in the mix are 4.5, 5.0, 5.5, 6.0 and $6.5 \%$.

Table 2: Result of Preliminary Test on Aggregate materials

\begin{tabular}{llll}
\hline Test Conducted & Code Used & Code Limits & Test Result \\
\hline Aggregate Crushing Value (\%) & BS 812 Part 112 & Max. 25 & 22.8 \\
Aggregate Impact Value (\%) & BS 812 Part 111 & Max. 25 & 16.3 \\
Aggregate Los Angeles Abrasion Value (\%) & ASTM C131 & Max. 30 & 18.9 \\
Specific Gravity (Coarse Aggregate) (Gc) g/cc & ASTM C127 & $2.55-2.75$ & 2.70 \\
Aggregate Moisture Absorption (\%) & BS 812 Part 2 & Max. 2 & 1.4 \\
Coarse Aggregate Flakiness Index & BS812 Part 105 & $<35$ & 26 \\
Specific Gravity (Fine Aggregate) (Gf) g/cc & ASTM C128 & $2.55-2.75$ & 2.63 \\
Bulk Specific Gravity of Total Aggregate (Gsb), g/cc & ASTM C127 & - & 2.71 \\
\hline
\end{tabular}

Table 3: Result of Preliminary Test on Cement Filler

\begin{tabular}{cccc}
\hline Test Conducted & Code Used & Code Specification & Result Obtained \\
\hline Specific gravity & ASTM C188 & 3.15 & 3.15 \\
Initial Setting time (minutes) & BS EN 196 Part 3 & Min. 45 & 98 \\
Final Setting time (minutes) & BS EN 196 Part 3 & Max 375 & 230 \\
Soundness (mm) & BS EN 196 Part 3 & Max. 10 & 3.5 \\
\hline
\end{tabular}

Table 4: Combined Material Mix and Range of Specification Requirements

\begin{tabular}{ccccc}
\hline $\begin{array}{c}\text { Sieve Size } \\
(\mathrm{mm})\end{array}$ & $\begin{array}{c}\text { Percentage } \\
\text { Retained }\end{array}$ & $\begin{array}{c}\text { Cumulative } \\
\text { Percentage Retained }\end{array}$ & $\begin{array}{c}\text { Cumulative Percentage } \\
\text { Passing }\end{array}$ & $\begin{array}{c}\text { Range of Percentage Passing } \\
\text { (ASTM D3515) }\end{array}$ \\
\hline 25.00 & - & - & 100 & 100 \\
19.00 & 2.7 & 2.7 & 97.3 & $95-100$ \\
12.50 & 9.7 & 12.4 & 87.6 & $82-92$ \\
9.50 & 9.2 & 21.6 & 78.4 & $73-86$ \\
6.30 & 12.7 & 34.3 & 65.7 & - \\
4.75 & 10.3 & 44.6 & 55.4 & $49-67$ \\
2.36 & 10.9 & 55.5 & 44.5 & $33-53$ \\
1.18 & 12.0 & 67.5 & 32.5 & - \\
0.60 & 10.0 & 77.5 & 22.5 & $14-36$ \\
0.30 & 7.7 & 85.2 & 14.8 & $11-28$ \\
0.15 & 6.2 & 91.4 & 8.6 & - \\
0.075 & 2.1 & 93.5 & 6.5 & $6-11$ \\
Pan & 6.5 & 100 & - & - \\
\hline
\end{tabular}




\subsection{Marshall Specimen Compaction}

According to [30], specimen compaction is a function of design traffic category. Application of 35, 50 and 75 blows respectively on each side of specimen depicts light $\left(<10^{4} \mathrm{EAL}\right)$, medium $\left(10^{4}\right.$ to $\left.10^{6} \mathrm{EAL}\right)$ and heavy traffic $\left(>10^{6} \mathrm{EAL}\right)$ categories. VIM in the specimen correlates with the degree of compaction. Though, a VIM range of 3 to $5 \%$ which supports use of additives is suggested by [31]a moderate VIM of 4\% shows that excessive cracking supported by upper limit (5\% VIM) and plastic flow and bleeding supported by the lower limit (3\% VIM) can be mitigated. [32] recommends 5\% VIM for 75 blows if traffic is in excess of $5^{*} 10^{6} \mathrm{EAL}$.

\section{ANALYSIS AND DISCUSSION}

\subsection{Bitumen test}

The test conducted on unmodified bitumen and HDPP modified 60/70 penetration bitumen used satisfied various codes requirements for ductility, penetration, softening point, specific gravity, solubility and flash and fire point tests. The factors that can affect ageing of bitumen are temperature, exposure to oxygen, UV light, chemical components and bitumen structure [33]. As the consequences of ageing, volatilization followed by oxidation and minor cases of polymerization impart on short and long term ageing of the bitumen binder during its service. From TFOT conducted to simulate short term ageing, 0 to $2.5 \%$ HDPP modified bitumen did not have considerable loss of volatiles which agrees with [34], but 2.5\% HDPP content led to changes in physical and rheological characteristics exhibited by loss of ductility, elasticity and retained penetration. Considering the recommendations of penetration grades bitumen [32], an optimum HDPP content of $2.0 \%$ meets TFOT requirements for retained penetration, ductility and loss in mass.

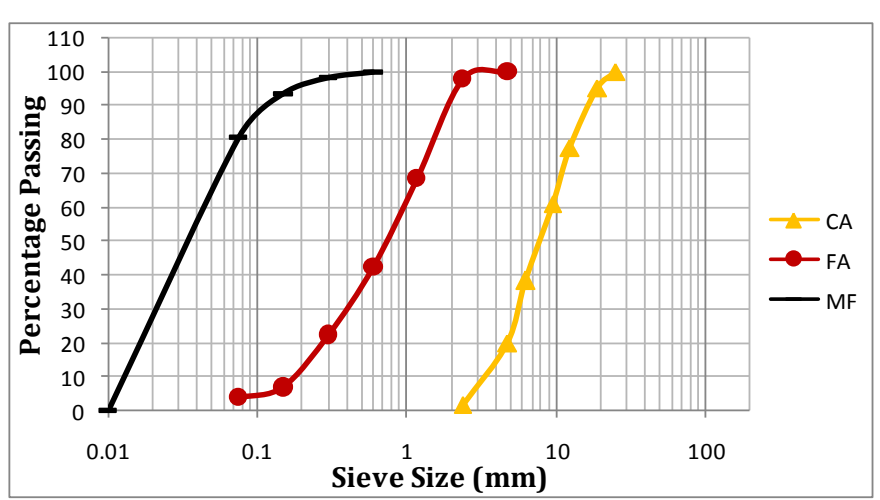

Figures 3: Grading curve for mineral materials

\subsection{Preliminary Tests on Mineral Aggregates}

According to Aggregate suitability affects physical and mechanical properties and durability of asphalt [35]. Mineralogy cum petro-graphic nature of rock formation as well as shape and size impart on strength, traffic wear and weather resistance of aggregates in asphalt [36, 37].Strength tests carried out on mineral aggregates presented in Table 2 satisfied relevant codes recommendations adjudging that the material is strength, tough, dense and abrasion resistant and can stand the test of both serviceability and durability requirements of asphalt mixtures within the designed life.

\subsection{Aggregate Grading and Blending}

The results of coarse and fine aggregates and filler material grading are shown in Figures 3. The figure is the combined aggregate envelope and the distribution of various materials. Figure 4 shows the blending of the materials which have been sandwiched between the envelope of the ranges of passing sieves sizes specified by [38].Aggregate grading is the foremost and most crucial factor affecting rutting and permanent deformation. Good bond enhancement of materials, interlocking friction grip and good packaging density are predicated upon the characteristics, nature and grading of aggregates [39]. The nature of aggregate skeleton imparts upon the matrix of the mix and structural benefit of strength and durability that withstand stresses from vehicle tire [40]. Grading in Figure 4 passes through the middle of the envelop while the closer the curve to lower limit, the more strength is compromised even as the voids reduces. Conversely, aggregate curve closer to the upper boundary of the envelop entrains more voids whole could affect the rate of oxidation and ageing of asphalt. As in Figure 4, the combined grading which passes through the middle of the grading envelop supports job mix formula and is considered to be rutting resistant $[38,40]$.

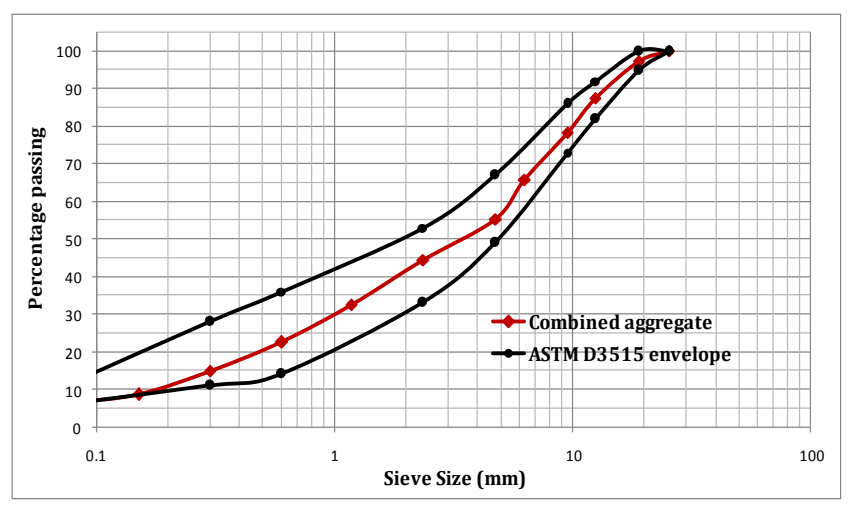

Figure 4: Combined aggregate envelope CA: Coarse Aggregate, FA: Fine Aggregate and MF: Mineral Filler 


\subsection{Marshall Test Results for HDPP Polymer Modified Asphalt}

The results of stability, flow and volumetric analysis (VIM; void in mix, VMA; void in mineral aggregate and VFB; void filled with bitumen) for wet process (polymer bitumen) and dry process (fibre reinforced) asphalt concrete are shown in Figures 5 to 10. The summary of the findings as follows:

1. The result of stability steadily increased; reaching the optimum as HDPP content increased. The optimum stability for wet process is $27.68 \mathrm{kN}$ and this occurred at $2.0 \%$ HDPP content. The inclusion of HDD Paccounted for an improvement of $90.63 \%$ in strength compared to 0\% HDPP (control). This agrees with the work of [41]. The optimum bitumen content is $5.5 \%$. The initial increase is as a result of increase in surface tension which coagulates the loosely bonded molecular structure of bitumen. Beyond the optimum, the polymer bitumen becomes more plastic than viscoelastic.

2. The Compacted Density of Mix (CDM) of the mix decreased as HDPP increased. This is because incorporating HDPP which is less dense compared to the other components of the mix lowers the unit weight of the compacted asphalt mix irrespective of the percentage voids attained. The optimum bitumen content is $5.5 \%$.0ptimum CDM translates into adequate void which supports good internal strength and deformation to the optimum of stress bearing capacity [41].Before the optimum, the voids increases exposing the mix early oxidation of bitumen leading to stripping and cracking, but above optimum CDM, rutting is triggered by increasing bitumen content because of deformation susceptibility of bitumen even at ambient temperature [39]

3. Since the range of specification requirement of [30] for VIM is $3-5 \%$ and the average (i.e. $4.0 \%$ VIM) is usually preferred, Increasing HDPP content from 0 to $3.0 \%$ lowers what may be adjudged optimum bitumen and thus, reduced bitumen consumption as increasing HDPP increase toughness and lowering the voids entrained in the mix. Higher VIM values beyond the upper range $5 \%$ causes oxidation of bitumen and results to quick ageing and loss of durability while lower than 3.0\% VIM causes fatigue cracking [32]. Optimum VIM strikes the balance between two extreme scenarios of stiffness leading to premature cracking on one side and excessive deformation flow because of excessive bitumen on the other [39]. Thus, an optimum VIM of in between the range of 3-5\% would forestall against the two unfavourable failure scenarios - stiffness cracking and deformation.
4. The flow results at optimum bitumen content of $5.5 \%$ decreased from $2.8 \mathrm{~mm}$ to $2.3 \mathrm{~mm}$ respectively for increasing HDPP contents of 0 to $3.0 \%$ because of increasing interfacial tension created by surface tension and colloids of bitumen and polymer that forms increasing micelles of unit cells [19].This trend lowers deformation as micelle units galvanises the strength of the intermolecular bonds in the asphalt matrix even at increasing temperature defines its deformation resilience that lowers creep and rutting. When HDPP is high, the mixture becomes phase inversed leading to flocculation and destabilisation [42]. At this stage of phase separation, a transition from viscoelasticity phase to plastic phase mix occurs because of high stiffness which causes premature cracking [41].

5. Initially, as bitumen content increases, the value of VMA generally decreases down to 'refusal density'. The optimum VMA occurs at the minimum point around the optimum bitumen content. Beyond this 'refusal density', a further increase in bitumen content increases VMA as a consequent of aggregate structure becoming overfilled with bitumen leading to deformation [28]. A minimum VMA of $12.0 \%$ at average $4.0 \%$ VIM is recommended by Marshall criteria for nominal aggregate size of 1" (25mm). For all HDPP contents of 0 to $3.0 \%$, optimum VMA increased. These values meet the recommendation of the code [30]. VMA increased because the film thickness of coated aggregate and effective bitumen content that does not include absorbed bitumen increased. The optimum bitumen content is $5.5 \%$.

6. At optimum bitumen content of $5.25 \%$, the VFB for 0 to 2.0\% HDPP asphalt concrete meet the Marshall criteria for heavy traffic whose values range between 65 to $75 \%$ VFB, according to code specification [30]. Higher values of VFB often lead to bleeding of bitumen and corrugation of asphalt pavement.

\section{CONCLUSION}

The following conclusions could be made from the research:

1. Thin Film Oven Test (TFOT) conducted for both pure and PM asphalt showed adequate age resistances for 0 to $2.5 \%$ HDPP contents that can withstand traffic loading, favorable service conditions and durability of asphalt.

2. For Marshall parameters for HDPP PM asphalt, 2.0\% HDPP content gave improved stability increase of $92.5 \%$ and flow resilience or reduction of $13.0 \%$. 


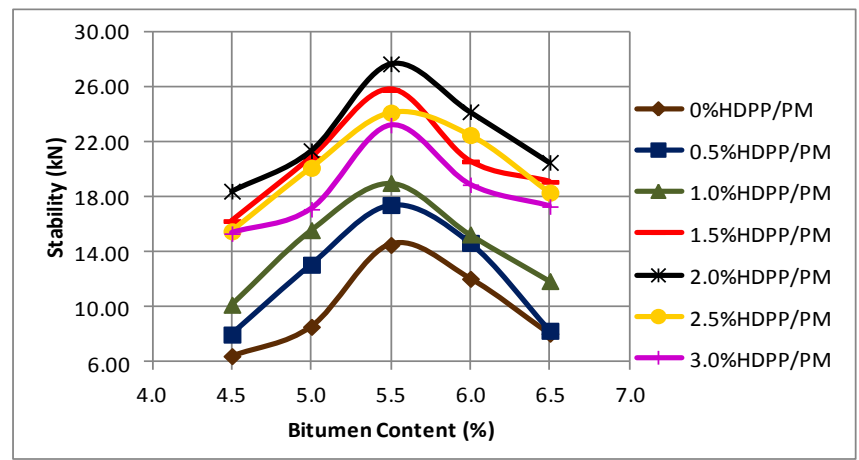

Figures 5: Relationship between Stability and Bitumen Content

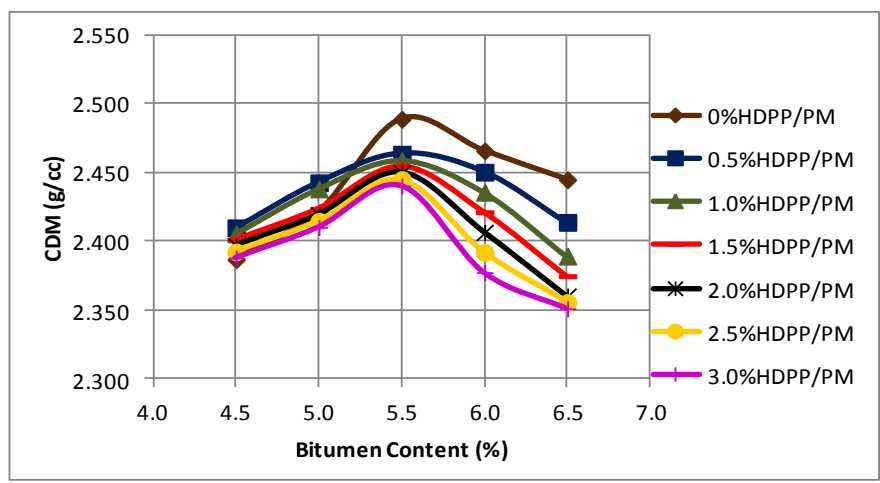

Figures 7: Relationship between CDM and Bitumen Content

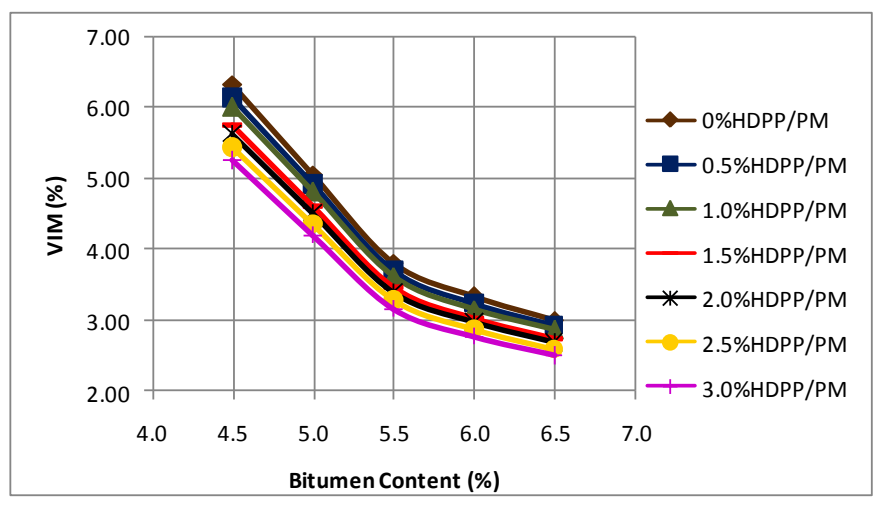

Figures 9: Relationship between VIM and Bitumen Content

3. The void properties (VMA, VIM and VFB) are enhanced to resist moisture susceptibility and improve on durability.

4. The Results of both Marshall parameters and void analysis obtained are better enhanced with improved properties than 0\% HDPP (control) and meets the Marshall specifications for Asphalt Institute, (1997) for heavy traffic situation of more than $10^{6}$ ESAL considered and hence, could mitigate pavement distresses.

\section{REFERENCES}

[1] Ayo O. and Ikechukwu A. D. "A Project Management Perspective to the Management of Federal Roads in Nigeria: A Case Study of Minna-Bida Road". Journal

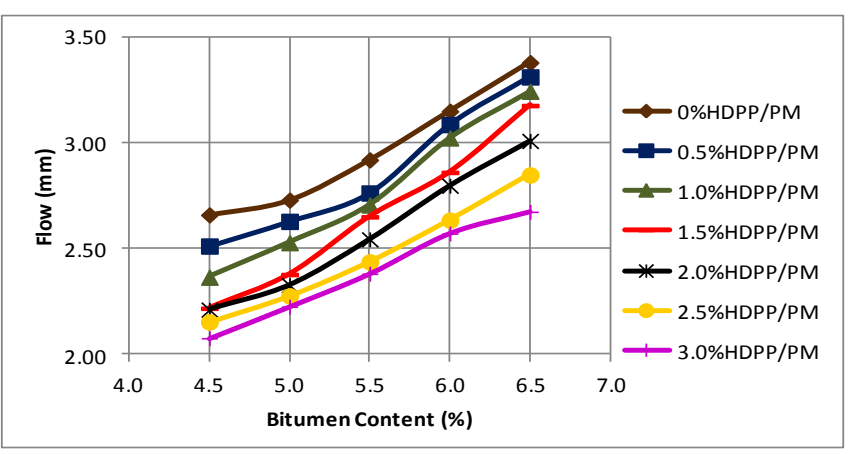

Figures 6: Relationship between Flow and Bitumen Content

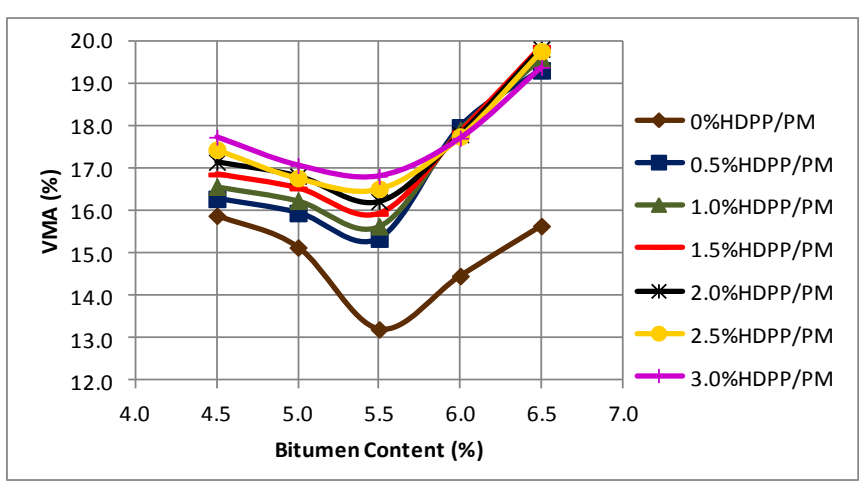

Figures 8: Relationship between VMA and Bitumen Content

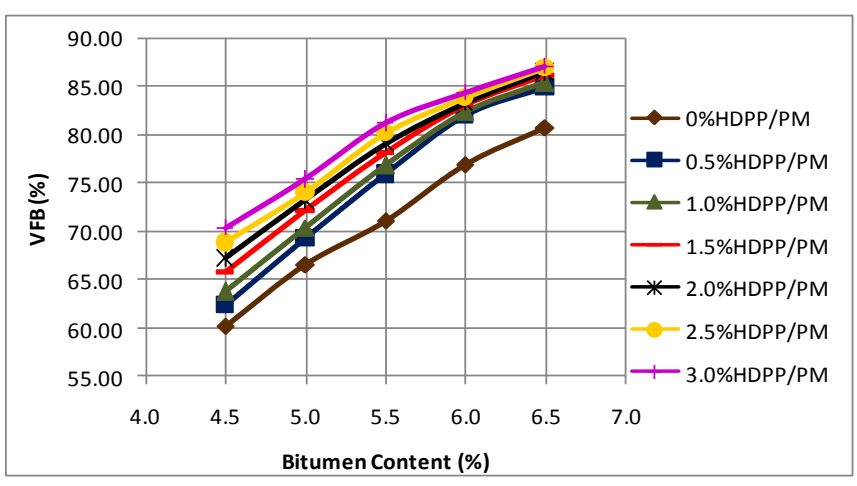

Figures 10: Relationship between VFB and Bitumen Content

of Finance and Economics. Vol. 1, No. 4, 54-61, 2013.

[2] Owolabi, A. 0. "Towards an Improved Road Network for the Survival of Nigerian Economy". Proceedings of the Maiden National Engineering Conference, Federal Polytechnics, Bauchi, pp 121$130,1996$.

[3] Road Sector Development Team. Federal roads development project: Environmental/social screening and scoping report - final report: BeninAkure-Ilesa Road, Federal Government of Nigeria, 2010.

[4] Pison-REIPPS. Compendium report on road infrastructure and related development in Nigeria an investor's manual, Federal Ministry of Works: Abuja, Nigeria, 2013. 
[5] Ogundipe, O. M. "Roads pavement failure caused by poor soil properties along Aramoko-Ilesha Highway", Nigeria. Journal of Engineering and Applied Sciences, 3(3), pp 239-241, 2008.

[6] Hijab M., Zaynab A. B. l. and Hadi A. A. Road Pavement Failure Induced by Poor Soil Properties Along Gombi-Biu Highway, Nigeria. Journal of Engineering and Applied Science. Vol. 4, pp 22-27, 2012.

[7] Abiola, O. S., Owolabi, A. O., Odunfa, S. O. and Olusola, A. "Investigation into Causes of Premature Failures of Highway Pavements in Nigeria and Remedies". A paper presented at the 2010 Nigeria Institution of Civil Engineers (NICE) Conference, Federal University of Technology, Akure, Nigeria, 2010.

[8] Otuoze, H. S.; Shuaibu, A. A.; Ahmed, H. A.; Garba A.; and Yusuf O. K. "Binding Properties of Poly-Vinyl Chloride Thermoplastic Waste Modified Bitumen for Flexible Pavement Mix". Proceedings of 2014 Nigeria Engineering Conference, Faculty of Engineering, Ahmadu Bello University, Zaria, Nigeria, pg 502 - 510, 2014.

[9] Jimoh, Y. A., Afolabi, A. A. and Onundi, A. A. Menace of Pavement Failures: Implications of Traffic Analysis and Management. 3rd Proceeding, Annual Conference of Civil Engineering, Department of Civil Engineering, University of Ilorin, Nigeria, 2011.

[10] Kumar P., Chandra S and Bose S. "Rheology of Polymer Modified Bitumen", Highway Research Bulletin, Vol. 71, Pp. 119-135, 2014.

[11] Hamzah, M. O., Mohamed, A. Aand Ismail, H. "Laboratory Investigation of The Properties of a Newly Developed Crumb Rubber Modified (Cri1) Asphalt Mixtures". Emirates Journal for Engineering Research, 11(2), 67-72, 2006.

[12] Abdelaziz M., Mohamed R. K. \& Herda, Y. K. "Fatigue and Deformation Properties of Glass Fiber Reinforced Bituminous Mixes". Journal of the Eastern Asia Society for Transportation Studies, Vol. 6, Pp. 997 - 1007, 2005.

[13] Airey G. D., Rahman, M. M., Collop, A. C. "Absorption of Bitumen into crumb rubber using the basket drainage method". International Journal of Pavement Eng. Vol. 4 (2):105-19, 2003.

[14] Shen, J., \& Amirkhanian, S. "The Influence of Crumb Rubber Modifier (CRM) microstructure on the high temperature properties of CRM binder". Int. J. Pavement Eng. Vol.6 (4):265-71, 2005.

[15] Brown, S. F., Rowlett, R. D. \& Boucher, J. L. “Asphalt Modification. Proceedings of the Conference on the United States Strategic Highway Research Program: Sharingthe Benefits". London, Thomas Telford (pub). p. 181-203, 1990.

[16] Sperling L. H. Introduction to Physical Polymer Science. Lehigh University Bethlehem, Pennsylvania
John Wiley \& Sons, Inc. Hoboken, New Jersey. $4^{\text {th }}$ Edition Pg 473-536, 2006.

[17] Mohammed S and Patil, K. A. "Rheological Properties of Recycled Low Density Polyethylene and Polypropylene Modified Bitumen". International Journal of Advanced Technology in Civil Engineering, ISSN: 2231 -5721, Volume-2, Issue-2, Pg; 24-26, 2013.

[18] feiffer, J., Saal, R. N. J. "Asphaltic Bitumen as Colloid System". The Journal of Physical Chemistry, Vol. 44 (2), pp. 139-149, 1940.

[19] Rosen M. J. and Kunjappu JT Surfactants and Interfacial Phenomena (4th ed.). Hoboken, New Jersey: John Wiley \& Sons. p. 1. ISBN 1-118-229029. 2012 .

[20] Raki, L., Masson, J. F., Collins, P. "Rapid Bulk Fractionation of Maltenes into Saturates, Aromatics, and Resins by Flash Chromatography". Energy \& Fuels, 14 (1), pp. 160-163, 2000.

[21] Carbognani, L., Gonzalez, M.F., Pereira-Almao, P."Characterization of Athabasca Vacuum Residue and Its Visbroken Products. Stability and Fast Hydrocarbon Group Type Distributions". Energy \& Fuels, 21, pp. 1631-1639, 2007.

[22] Myer K. Mechanical Engineers' Handbook, Materials and Engineering Mechanics. John Wiley \& Sons, Technology \& Engineering, pages 359-364, 2015.

[23] Haylock, J. C., Phillips, R. A. and Wolkowicz, M. D. in J. Scheirs and W. Kaminsky,eds., Metallocene-Based Polyolefins: Preparation, Properties and Technology, Vol. 2,John Wiley \&Sons, Inc., New York, p. 203- 333, 2000.

[24] Galli, P., Haylock, J. C. and Simonazzi, T. Manufacturing and properties of polypropylene copolymers, In: J. Karger-Kocsis: Polypropylene Structure, Blends and Composites: 2. Copolymers and Blends, S. 1-24, Chapman \& Hall, London Glasgow, 1995.

[25] Busico, V., Corradini, P., DeBiasio, R., Landriani, L., and Segre A. L.Catalyst design for tailor-made polyolefin. Macromolecules 27, 4521, 1994.

[26] ASTM D1505-10 Standard Test Method for Density of Plastics by the Density-Gradient Technique. ASTM International (ASTM) 100 Barr Harbour Drive West Conshohocken, PA 19428-2959, 2010

[27] BS EN 932 - Testing General Properties of Aggregates. Part 1, Method of Sampling, BSI, London, 2003.

[28] BS EN, 933-1, Testing for General Properties of Aggregates, Part 1; Determination of Particle Size Distribution - sieve method, BSI, London, 2003.

[29] Asphalt Institute. Mix Design Methods for Asphalt Concrete and Other Hot-Mix Types, Manual SeriesNo. 2, Sixth Edition, The Asphalt Institute, Lexington, KY, 1994. 
[30] Asphalt Institute. Mix Design Methods for Asphalt, Manual Series No. 2 (MS-02). The Asphalt Institute. Lexington, KY, 1997.

[31] AASHTO 312-01, "Preparing and Determining the Density of Hot-Mix Asphalt (HMA) Specimens Means of the Superpave Gyratory Compactor." Standard Test Method for Transportation by Materials and Methods of Sampling and Testing, Part II-Tests, Twentieth Edition, 2001.

[32] ORN 19, (2003), A guide to the Design of Hot Mix Asphalt in Tropical and Sub-tropical Countries, Overseas Road Note 1 Crowthorne TRL.

[33] Tahirou, M. Influence of Bitumen Ageing on Asphalt Quality, Comparison Between Bitumen and Asphalt Ageing. A MSc Thesis in Physical Land Resources, Inter University Programme of Universiteit Gent and Vrije Universiteit Brussel, Belgium. Pg 13, 2009.

[34] Zoorob, S. E., Collop, A. C., and Stephen, F. Performance of Bituminous and Hydraulic Materials in Pavements, Proceedings of the Fourth European Symposium, Bitmat4, Nottingham, UK, P331, 2002.

[35] Cui S., Blackman B. R. K., Kinloch A. J., Taylor A. C. Durability of asphalt mixtures: Effect of aggregate type and adhesion promoters International Journal of Adhesion and Adhesives 54:100-111, 2014,

[36] Bulevičius M., Petkevičius K., Žilionienè D., Drozdova K. Testing Of Physical-Mechanical Properties of Coarse. Modern Building Materials, Structures And Techniques. 10 ${ }^{\text {th }}$ International Conference, Faculty of Civil Engineering, Vilnius Gediminas Technical University, May 19-21 Vilnius, Lithuania, 2010, Pg1094-1098. 2010,

[37] Horgnies M., Darque-Ceretti E., Fezai H., Felder E. Influence of the interfacial composition on the adhesion between aggregates and bitumen: investigations by EDX, XPS and peel tests. Int J Adhes Adhes 31:238-47. 2011;

[38] ASTM D3515. Standard Specification for Hot-Mixed, Hot-Laid Bituminous Paving Mixtures, American Society for Testing and Materials, Conshohocken, Pennsylvania, 1996.

[39] Golalipour A., Jamshidi A. E., Niazi Y., Afsharikia Z., Khadem M. Effect of Aggregate Gradation on Rutting of Asphalt Pavements. SIIV - 5th International Congress - Sustainability of Road Infrastructures, Procedia - Social and Behavioral Sciences 53440 - 449, 2012.

[40] Coenen A.. Image Analysis of Aggregate Structure Parameters as Performance Indicators of Rutting Resistance, University of Wisconsin-Madison, PhD. thesis, 2011.

[41] Serkan P, Çevik A and Uşar Ü. Prediction of Marshall test results for polypropylene modified dense bituminous mixtures using neural networks. Expert Systems with Applications. 2010; 37(6):4660-4670, .2009

[42] Kamaruddin I., Habib, N. Z., Tan, I. M., Komiyama M., and Napiah M. Effect of Polymer Dispersion on the Rheology and Morphology of Polymer Modified Bituminous Blend: Mechanisms, Modelling, Testing, Detection and Prevention Case Histories. A. Scapas et al. (Edns. ), 7th RILEM International Conference on Cracking in Pavements, RILEM Series, pp 859868, 2012.

[43] Ijevu U. A., Idigbe K. I. and Ebewele R. O. A New Beginning for the Petro-Chemical Industry in Nigeria: Meeting Challenges Through an Effective Exploitation of Natural Gas. Academic Research International, Vol.4, No. 5, Pg 100-109. 2013. 